Bull. Fac. Agric., Cairo Univ., 66:130-141 (2015).

\title{
EFFECT OF DIFFERENT LEVELS OF IRRIGATION ON GROWTH, FLOWERING AND CHEMICAL CONSTITUENTS OF Jatropha curcas PLANTS GROWN IN SANDY SOIL
}

(Received: 21.1.2015)

\author{
By \\ N. A. El-Shanhorey \\ Department of Botanical Garden Research - Antoniades, Horticultural Research Institute, \\ Agriculture Research Center, Alexandria, Egypt.
}

\begin{abstract}
This investigation was carried out during 2012, 2013 and 2014 seasons on Jatropha curcas grown in plastic pots of $40 \mathrm{~cm}$ diameter at Antoniades Research Branch, Horticulture Research Institute, A.R.C., Ministry of Agriculture, Alexandria, Egypt. The study was a trial to investigate the effect of different levels of irrigation $(20,30,40,50,60,70,80,90$ and $100 \%$ of the field capacity) on the vegetative growth, yield production and some chemical constituents of Jatropha curcas plants grown in sandy soil. The results revealed that the highest level of available moisture (100\% of field capacity) gave the highest significant values of plant height, leaf number, leaf dry weight, leaf area, stem diameter, stem dry weight, branch number per plant, root length, root dry weight, fruit yield per plant, seed yield per plant, total chlorophyll content, carbohydrate content, proline content and relative water content. In general, the results recommended that irrigating the cultivated Jatropha curcas in the sandy soil daily using irrigation level not less than $80 \%$ of field capacity gave the best vegetative growth, yield production and chemical analysis of Jatropha curcas plants, compared with the lower irrigation levels used in this study.
\end{abstract}

Key words: Jatropha curcas, drought tolerance, vegetative growth, yield production, chemical analysis.

\section{INTRODUCTION}

Jatropha curcas (purge nut/physic nut) is a major succulent crop plant, shrub and tree (same are deciduous, like resistant Jatropha curcas L.), belongs to the family Euphorbiaceae. It is a drought tolerant perennial plant, grows well in marginal/poor soil and is widely distributed throughout many tropical and sub-tropical regions throughout America, Africa and Asia (Takeda, 1982).

While this plant grows well in low-rainfall conditions, requiring only about $200 \mathrm{~mm}$, it can also respond to higher rainfall up to $1200 \mathrm{~mm}$, particularly in hot climatic conditions. This plant can withstand extremely low air humidity and can tolerate long-term water stress by shielding most of its leaves to reduce transpiration. Due to the above mentioned characteristics, it has received special attention in many countries and is one of the main crops to be promoted for growing in marginal lands for biodiesel production (Kumar et al., 2011). Jatropha, the wonder plant, produces seeds with an oil content of $37 \%$. Jatropha is gaining importance commercially as a green fuel source and is being advocated for development of wastelands and dry lands. Currently the oil from Jatropha seeds is used as biodiesel fuel in many developing and developed countries (Dong, 2004).

This plant is characterized by its high drought and salinity tolerance (Maes et al., 2009 and Silva et al., 2010), high oil content, rapid growth and adaptability to widely different agro-climatic conditions (Divakara et al., 2010). Jatropha seeds have received much attention because their oil can be converted into biodiesel (Openshaw, 2000) and because Jatropha plants can improve soil resistance to wind and water erosion under flooded conditions (Ogunwole et al., 2008).

Water is essential for various metabolic activities. Its deficiency induces water stress on vegetation in combination with soil, plant and climate. All these factors interact to determine the water absorption and loss by the plants (Baquedano and Castillo, 2006). In arid and semi-arid regions, plants are often exposed to 
water deficit stress, also known as moisture stress which negatively influence plant growth and biomass productivity (Wu et al., 2008, Efeoglu et al., 2009 and Zhang et al., 2011). The plants can avoid moisture stress by maximizing water uptake i.e., absorbing ground water by deep roots or minimizing water loss through stomatal closure, small thick leaves, etc. (Kozlowski and Pallardy, 2002). The morphological and physiological nature may lead to some adaptation to moisture stress which varies considerably among species (Souza et al., 2004). The apparent consequences of moisture stress are the progressive decline in photosynthetic capacity though photosynthetic system found to be resistant to irrigation levels linked with stomatal closure (Cornic, 2000). The reduced leaf water reserve in relation to the limiting transpiration rate (Baquedano and Castillo, 2006) eventually impairs biomass accumulation (Osipova et al., 2011).

Water is a major constituent of tissues, a reagent in chemical reaction, a solvent and mode of translocation for metabolites and minerals within plant and is essential for cell enlargement through increasing turgor pressure. With the occurrence of water deficits many of the physiological processes associated with growth are affected and under severe deficits, death of plants may result.

The objective of this investigation was to study the effects of using different levels of field capacities (irrigation levels) on the vegetative growth, seed yield characteristics and some chemical analyses of Jatropha grown in sandy soil under the conditions of Alexandria, Egypt.

\section{MATERIALS AND METHODS}

The present study was carried-out at Antoniades Research Branch, Horticultural Research Institute, A.R.C. Alexandria, Egypt during the three successive seasons of 2012, 2013 and 2014. The aim of this study was to evaluate the effects of stress irrigation water on Jatropha curcas plants grown in sandy soil under the circumstances of Alexandria.

On the $15^{\text {th }}$ of February, 2012, 2013 and 2014 (in the first, second and third seasons, respectively) homogeneous seedlings of Jatropha curcas (70-80 cm height and 20-25 leaves per plant in average) were planted individually in plastic pots (40 $\mathrm{cm}$ diameter) filled with $20 \mathrm{~kg}$ of sandy soil. The chemical constituents of the soil were measured as described by Jackson (1958) in Table (1). On the $1^{s t}$ of March (in all seasons), the irrigation water treatments were initiated. On the $30^{\text {th }}$ of October (in all seasons), data were calculated on Jatropha curcas seedlings from March 2012 until October 2014 (in the three seasons). On the $30^{\text {th }}$ of October in the three seasons, the plants were harvested.

Tap water was used as a source of irrigation water. After that the regime of irrigation levels was started. Nine irrigation levels were used to keep the soil moisture at the field capacity of the sandy soil at 100, 90, 80, 70, 60, 50, 40, 30 and $20 \%$. The reduction in the moisture level of each treatment was determined daily by using Moisture Tester Model KS-DI (Gypsum Block "Fig. 1") during the growing seasons. The amounts of water of different treatments were added daily to each pot to keep the soil moisture of each treatment at the corresponding percentage. At the end of the experiment the total amount of irrigation water for each treatment was calculated and presented in Tables ( $2 \mathrm{a}, \mathrm{b}$ and $\mathrm{c}$ ). The field capacity of the sandy soil was determined by the pressure Cooker method at 1/3 atm., as described by Israelsen and Hansen (1962). Table (3) shows meteorological data during 2012, 2013 and 2014 seasons under the circumstances of Alexandria.

In the third season, all plants received NPK chemical fertilization using soluble fertilizer (Milagro Aminoleaf 20-20-20) at the rate of $3 \mathrm{~g} /$ pot. Fertilization was repeated every 30 days throughout the growing season (from the $1^{\text {th }}$ of March till the $30^{\text {th }}$ of October). In addition, weeds were removed manually upon emergence.

Table (1): Some chemical analyses of the used sandy soil for the three successive seasons 2012,2013 and 2014.

\begin{tabular}{|c|c|c|c|c|c|c|c|c|c|}
\hline \multirow[t]{2}{*}{ Season } & \multirow[t]{2}{*}{ pH } & \multirow{2}{*}{$\begin{array}{c}\mathrm{EC} \\
\left(\mathrm{dSm}^{-1}\right)\end{array}$} & \multicolumn{4}{|c|}{ Soluble cations (mg/l) } & \multicolumn{3}{|c|}{ Soluble anions (mg/l) } \\
\hline & & & $\mathrm{Ca}^{++}$ & $\mathrm{Mg}^{++}$ & $\mathrm{Na}^{+}$ & $\mathbf{K}^{+}$ & $\mathrm{HCO}_{3}^{-}$ & $\mathrm{Cl}^{-}$ & $\mathrm{SO}_{2}^{--}$ \\
\hline 2012 & 7.87 & 1.43 & 3.1 & 2.8 & 6.1 & 0.8 & 3.0 & 6.1 & 2.0 \\
\hline 2013 & 7.92 & 1.51 & 3.4 & 3.4 & 6.4 & 1.1 & 3.5 & 6.5 & 2.4 \\
\hline 2014 & 7.89 & 1.47 & 3.2 & 3.0 & 6.2 & 0.9 & 3.2 & 6.3 & 2.2 \\
\hline
\end{tabular}




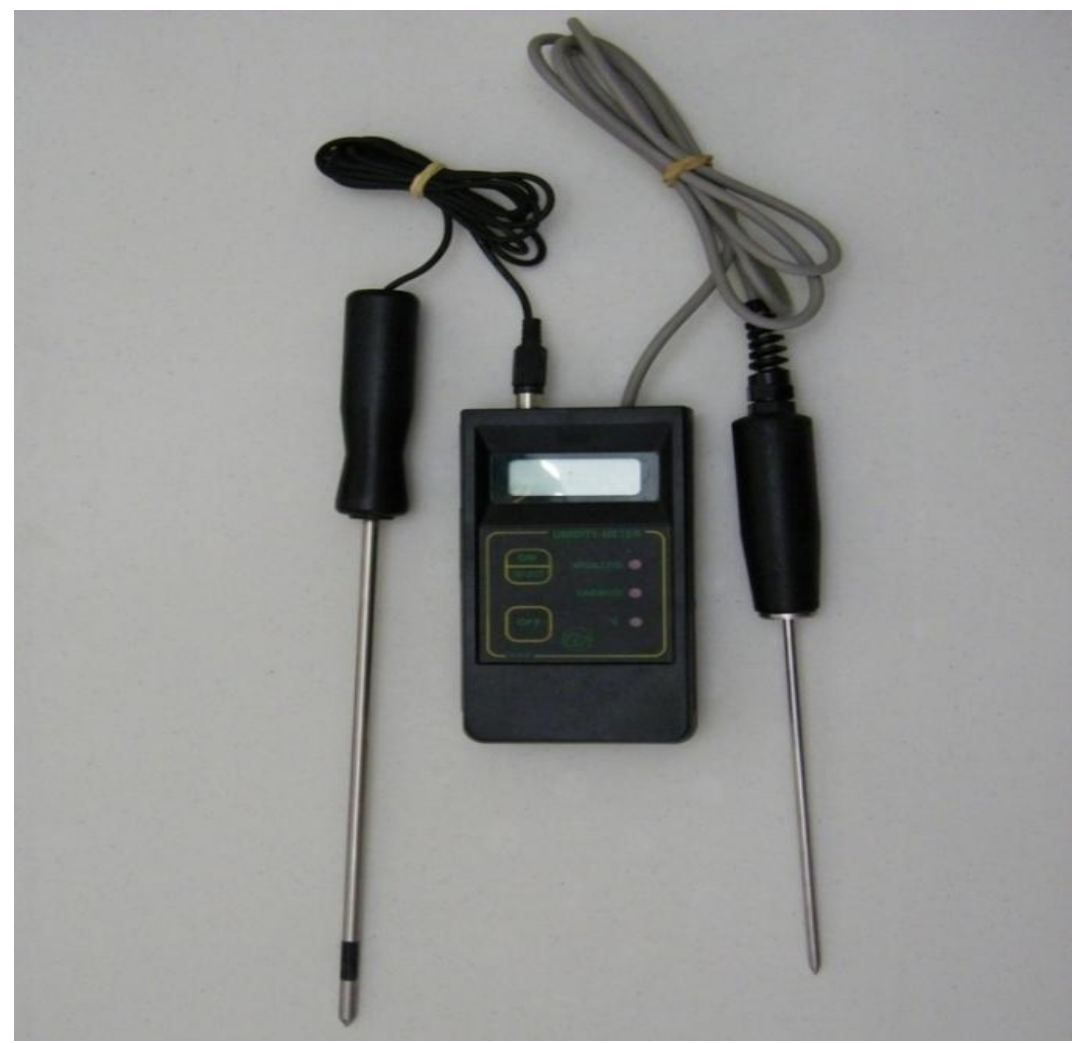

Fig.( 1): Gypsum Block (Model KS-DI).

Table (2a): Total amount of the water used for each plant (1/pot) in each treatment during the growing season of 2012.

\begin{tabular}{|c|c|c|c|c|c|c|c|c|c|}
\hline \multirow{2}{*}{$\begin{array}{c}\text { Field } \\
\text { Capacity }(\%)\end{array}$} & \multicolumn{9}{|c|}{ First season (2012) } \\
\hline & March & April & May & June & July & August & September & October & Mean \\
\hline $100 \%$ & 31.00 & 33.00 & 37.20 & 39.00 & 43.40 & 49.60 & 42.00 & 40.30 & 315.50 \\
\hline $90 \%$ & 27.90 & 29.70 & 33.50 & 35.10 & 39.10 & 44.70 & 37.80 & 36.30 & 284.10 \\
\hline $80 \%$ & 24.80 & 26.40 & 29.80 & 31.20 & 34.80 & 39.70 & 33.60 & 32.30 & 252.60 \\
\hline $70 \%$ & 21.70 & 23.10 & 26.10 & 27.30 & 30.40 & 34.80 & 29.40 & 28.30 & 221.10 \\
\hline $60 \%$ & 18.60 & 19.80 & 22.40 & 23.40 & 26.10 & 29.80 & 25.20 & 24.20 & 189.50 \\
\hline $50 \%$ & 15.50 & 16.50 & 18.60 & 19.50 & 21.70 & 24.80 & 21.00 & 20.20 & 157.80 \\
\hline $40 \%$ & 12.40 & 13.20 & 14.90 & 15.60 & 17.40 & 19.90 & 16.80 & 16.20 & 126.40 \\
\hline $30 \%$ & 9.30 & 9.90 & 11.20 & 11.70 & 13.10 & 14.90 & 12.60 & 12.10 & 94.80 \\
\hline $20 \%$ & 6.20 & 6.60 & 7.50 & 7.80 & 8.70 & 9.90 & 8.40 & 8.10 & 63.20 \\
\hline
\end{tabular}

Table (2b): Total amount of the water used for each plant (1/pot) in each treatment during the growing season of 2013.

\begin{tabular}{|l|c|c|c|c|c|c|c|c|c|}
\hline \multirow{2}{*}{$\begin{array}{c}\text { Field } \\
\text { Capacity(\%) }\end{array}$} & March & April & May & June & July & August & September & October & Mean \\
\hline $\mathbf{1 0 0} \%$ & 34.10 & 36.00 & 40.30 & 45.00 & 52.70 & 58.90 & 51.00 & 43.40 & $\mathbf{3 6 1 . 4 0}$ \\
\hline $\mathbf{9 0} \%$ & 30.70 & 32.40 & 36.30 & 40.50 & 47.50 & 53.10 & 45.90 & 39.10 & $\mathbf{3 2 5 . 5 0}$ \\
\hline $\mathbf{8 0} \%$ & 27.30 & 28.80 & 32.30 & 36.00 & 42.20 & 47.20 & 40.80 & 34.80 & $\mathbf{2 8 9 . 4 0}$ \\
\hline $\mathbf{7 0} \%$ & 23.90 & 25.20 & 28.30 & 31.50 & 36.90 & 41.30 & 35.70 & 30.40 & $\mathbf{2 5 3 . 2 0}$ \\
\hline $\mathbf{6 0} \%$ & 20.50 & 21.60 & 24.20 & 27.00 & 31.70 & 35.40 & 30.60 & 26.10 & $\mathbf{2 1 7 . 1 0}$ \\
\hline $\mathbf{5 0} \%$ & 17.10 & 18.00 & 20.20 & 22.50 & 26.40 & 29.50 & 25.50 & 21.70 & $\mathbf{1 8 0 . 9 0}$ \\
\hline $\mathbf{4 0} \%$ & 13.70 & 14.40 & 16.20 & 18.00 & 21.10 & 23.60 & 20.40 & 17.40 & $\mathbf{1 4 4 . 8 0}$ \\
\hline $\mathbf{3 0} \%$ & 10.30 & 10.80 & 12.10 & 13.50 & 15.90 & 17.70 & 15.30 & 13.10 & $\mathbf{1 0 8 . 7 0}$ \\
\hline $\mathbf{2 0} \%$ & 6.90 & 7.20 & 8.10 & 9.00 & 10.60 & 11.80 & 10.20 & 8.70 & $\mathbf{7 2 . 5 0}$ \\
\hline
\end{tabular}


Table (2c): Total amount of the water used for each plant (1/pot) in each treatment during the growing season of 2014.

\begin{tabular}{|l|c|c|c|c|c|c|c|c|c|}
\hline \multirow{2}{*}{$\begin{array}{c}\text { Field } \\
\text { Capacity(\%) }\end{array}$} & \multicolumn{9}{|c|}{ Third season (2014) } \\
\cline { 2 - 11 } & March & April & May & June & July & August & September & October & Mean \\
\hline $\mathbf{1 0 0} \%$ & 37.20 & 39.00 & 43.40 & 48.00 & 55.80 & 62.00 & 54.00 & 46.50 & $\mathbf{3 8 5 . 9 0}$ \\
\hline $\mathbf{9 0} \%$ & 33.50 & 35.10 & 39.10 & 43.20 & 50.30 & 55.80 & 48.60 & 41.90 & $\mathbf{3 4 7 . 5 0}$ \\
\hline $\mathbf{8 0} \%$ & 29.80 & 31.20 & 34.80 & 38.40 & 44.70 & 49.60 & 43.20 & 37.20 & $\mathbf{3 0 8 . 9 0}$ \\
\hline $\mathbf{7 0} \%$ & 26.10 & 27.30 & 30.40 & 33.60 & 39.10 & 43.40 & 37.80 & 32.60 & $\mathbf{2 7 0 . 3 0}$ \\
\hline $\mathbf{6 0} \%$ & 22.40 & 23.40 & 26.10 & 28.80 & 33.50 & 37.20 & 32.40 & 27.90 & $\mathbf{2 3 1 . 7 0}$ \\
\hline $\mathbf{5 0 \%}$ & 18.60 & 19.50 & 21.70 & 24.00 & 27.90 & 31.00 & 27.00 & 23.30 & $\mathbf{1 9 3 . 0 0}$ \\
\hline $\mathbf{4 0} \%$ & 14.90 & 15.60 & 17.40 & 19.20 & 22.40 & 24.80 & 21.60 & 18.60 & $\mathbf{1 5 4 . 5 0}$ \\
\hline $\mathbf{3 0} \%$ & 11.20 & 11.70 & 13.10 & 14.40 & 16.80 & 18.60 & 16.20 & 14.00 & $\mathbf{1 1 6 . 0 0}$ \\
\hline $\mathbf{2 0} \%$ & 7.50 & 7.80 & 8.70 & 9.60 & 11.20 & 12.40 & 10.80 & 9.30 & $\mathbf{7 7 . 3 0}$ \\
\hline
\end{tabular}

Table (3): Meteorological data at Central Laboratory of Agricultural Climate (CLAC) during 2012, 2013 and 2014 under the circumstances of Alexandria.

\begin{tabular}{|c|c|c|c|c|c|c|c|c|c|c|c|c|}
\hline & \multicolumn{3}{|c|}{$\begin{array}{c}\text { Maximum } \\
\text { temperature }\left({ }^{\circ} \mathrm{C}\right)\end{array}$} & \multicolumn{3}{|c|}{$\begin{array}{c}\text { Minimum } \\
\text { temperature }\left({ }^{\circ} \mathrm{C}\right)\end{array}$} & \multicolumn{3}{|c|}{$\begin{array}{c}\text { Mean } \\
\text { Humidity }(\%)\end{array}$} & \multicolumn{3}{|c|}{$\begin{array}{l}\text { Maximum sustained } \\
\text { wind speed }(\mathrm{Km} / \mathrm{h})\end{array}$} \\
\hline & 2012 & 2013 & 2014 & 2012 & 2013 & 2014 & 2012 & 2013 & 2014 & 2012 & 2013 & 2014 \\
\hline January & 16.7 & 18.7 & 19.8 & 8.7 & 8.8 & 9.5 & 73.8 & 74.9 & 79.3 & 25.6 & 22.7 & 16.4 \\
\hline February & 17.8 & 20.4 & 20.3 & 8.4 & 9.7 & 10.8 & 70.9 & 71.8 & 74.0 & 23.3 & 22.2 & 20.6 \\
\hline March & 20.1 & 23.4 & 22.7 & 11.0 & 12.4 & 12.3 & 68.2 & 64.2 & 68.6 & 23.9 & 24.5 & 22.9 \\
\hline April & 25.2 & 24.6 & 25.6 & 13.6 & 14.8 & 14.2 & 65.7 & 62.9 & 68.3 & 20.5 & 25.5 & 20.5 \\
\hline May & 28.2 & 28.7 & 28.5 & 17.4 & 18.8 & 17.6 & 67.2 & 68.0 & 64.8 & 20.9 & 24.6 & 22.8 \\
\hline June & 29.8 & 30.3 & 30.1 & 21.3 & 21.7 & 21.3 & 70.7 & 68.4 & 68.0 & 20.4 & 24.0 & 22.0 \\
\hline July & 32.0 & 30.2 & 30.8 & 24.6 & 23.4 & 23.5 & 72.0 & 71.4 & 71.4 & 21.4 & 23.8 & 22.1 \\
\hline August & 32.2 & 31.7 & 32.0 & 24.7 & 23.9 & 24.7 & 70.2 & 72.1 & 70.6 & 20.1 & 22.0 & 22.2 \\
\hline September & 30.2 & 30.5 & 31.1 & 21.7 & 21.8 & 22.2 & 69.4 & 67.4 & 66.6 & 19.3 & 21.9 & 20.5 \\
\hline October & 28.8 & 26.8 & 28.2 & 18.6 & 18.7 & 18.6 & 72.5 & 66.5 & 63.2 & 19.2 & 24.4 & 18.8 \\
\hline November & 25.4 & 25.2 & 24.2 & 16.1 & 15.4 & 15.4 & 74.5 & 73.4 & 63.3 & 17.8 & 19.3 & 20.0 \\
\hline December & 20.5 & 19.9 & 21.8 & 11.3 & 10.2 & 11.5 & 72.3 & 72.9 & 68.4 & 20.8 & 21.0 & 18.2 \\
\hline
\end{tabular}

\section{Data recorded}

(1) Vegetative growth parameters: Plant height $(\mathrm{cm})$, leaf number per plant, leaf area $\left(\mathrm{cm}^{2}\right)$, leaf dry weight per plant $(\mathrm{g})$, stem diameter $(\mathrm{cm})$, stem dry weight $(\mathrm{g})$, root length $(\mathrm{cm})$ and root dry weight $(\mathrm{g})$.

(2) Chemical analyses

-Chlorophyll contents were determined as SPAD unit in the fresh leaves of plants for the different treatments under the experiment at the end of the season using Minolta (chlorophyll meter) SPAD 502 according to Yadava (1986).

- Carbohydrate contents of the leaves were determined according to Dubios et al. (1956).

- Relative water content of the leaves (\%) in the fresh leaves were determined according to Barrs (1968) and Ritchie (1974).

-Proline content (\% of dry matter) in the leaves was determined according to Bates et al. (1973).

The layout of the experiment was a randomized complete blocks design (RCBD), with 9 treatments and 3 replicates, each replicate conceited (3 plants). The data of the three seasons were statistically analyzed as described by Snedecor and Cochran (1980). Means of all characters were compared by L.S.D. test at 0.05 level of significance.

\subsection{Plant height $(\mathrm{cm})$}

\section{RESULTS}

Data presented in Table (4) show that, in both three seasons, irrigation levels reduced the height of Jatropha curcas plants, compared to plants irrigated with $100 \%$ field capacity (control). Plants irrigated with $100 \%$ field capacity had the highest mean values of plant height $109.25,119.00$ and $134.83 \mathrm{~cm}$ in the first, 
second and third seasons, respectively. Moreover, reduceing the irrigation level caused steady significantly reduction in plant height, with the lowest irrigation level (20\% field capacity) giving significantly the shortest plants (with mean height of $84.75,90.75$ and 101.25 $\mathrm{cm}$ in the three seasons, respectively) than those receiving any other irrigation level.

\subsection{Number of leaves per plant}

The data presented in Table (4) show the effect of irrigation levels on the number of leaves formed on Jatropha curcas plants. Plants irrigated with $100 \%$ field capacity had the highest number of leaves $(23.33,29.83$ and 36.00) per plant in the first, second and third seasons, respectively. Accordingly, the lowest number of leaves 15.83, 21.83 and 29.50 per plant in the first, second and third seasons, respectively, was formed by plants irrigated using the lowest level.

\subsection{Leaf dry weight per plant (g)}

The results recorded in the three seasons in Table (4) show that the heaviest dry weights of leaves per plant $(31.09,38.43$ and $46.44 \mathrm{~g}$ in the first, second and third seasons, respectively), were obtained from plants irrigated with $100 \%$ field capacity. Irrigation with $20 \%$ field capacity decreased the dry weight of leaves significantly. Moreover, the recorded values were decreased steadily with reducing irrigation level. Accordingly, the lowest values $(22.88,31.45$ and $37.88 \mathrm{~g}$ per plant in the first, second and third seasons, respectively), were obtained from plants irrigated with $20 \%$ field capacity.

\subsection{Leaf area $\left(\mathrm{cm}^{2}\right)$}

The results recorded in the three seasons presented in Table (4) show that irrigation with $20 \%$ field capacity decreased the leaf area of Jatropha curcas plants, compared to plants irrigated with $100 \%$ field capacity (control). In the three seasons, plants irrigated with $100 \%$ field capacity (control) had the largest leaves area with means of $1082.90,2050.64$ and $3042.80 \mathrm{~cm}^{2}$ in the first, second and third seasons, respectively. The leaf area was decreased steadily with reducing irrigation to $20 \%$ field capacity. Accordingly, the smallest leaves with mean areas of 523.56, 700.92 and $1069.78 \mathrm{~cm}^{2}$ in the first, second and third seasons, respectively, were formed on plants irrigated with $20 \%$ field capacity.

\subsection{Stem diameter $(\mathrm{cm})$}

The data recorded on the stem diameter of Jatropha curcas plants in the three seasons in Table (5) show that reducing irrigation levels decreased stem thickness, compared to that of plants irrigated with $100 \%$ field capacity (control). In the third season, plants irrigated with $100 \%$ field capacity had the thickest stems, with a mean diameter of $(3.08,3.62$ and 4.37 $\mathrm{cm})$ in the first, second and third seasons, respectively. Reducing irrigation levels caused a steady reduction in stem diameter. This reduction in stem diameter was significant (compared to the control), which gave stem diameters of $(2.35,3.33$ and $3.74 \mathrm{~cm})$ in the first, second and third seasons, respectively.

\subsection{Stem dry weight (g)}

Data presented in Table (5) show that, in the third season, irrigation levels significantly decreased dry weight of stem of Jatropha curcas plants, compared to plants irrigated with $100 \%$ field capacity (control). Plants irrigated with $100 \%$ field capacity had the heaviest mean dry weight of stem 39.98, 43.47 and $52.52 \mathrm{~g}$ per plant in the first, second and third seasons, respectively. The dry weight of the stem showed a gradual reduction as irrigation level was gradually reduced. Accordingly, the lowest dry weight of stem $(32.16,40.14$ and $44.98 \mathrm{~g}$ per plant in the first, second and third seasons, respectively), was recorded in plants receiving the lowest irrigation level.

\subsection{Branch number per plant}

The data presented in Table (5) show the effect of irrigation levels on branch number per plant formed on Jatropha curcas plants. In the third season, plants irrigated with $100 \%$ field capacity had the highest branch number per plant (2.33, 4.66 and 8.00) branches per plant in the first, second and third seasons, respectively. Accordingly, the lowest branch number (1.00, 2.00 and 3.00 branches per plant in the first, second and third seasons, respectively), was formed by plants irrigated using the lowest irrigation level.

\subsection{Root length $(\mathrm{cm})$}

Data presented in Table (6) show that all the tested irrigation level treatments significantly decreased the root length $(\mathrm{cm})$ of Jatropha curcas, compared to plants irrigated with $100 \%$ field capacity (control). In the third season, plants irrigated with $100 \%$ field capacity had the highest mean root length $(81.83,89.25$ and $101.25 \mathrm{~cm}$ ) in the first, second and third seasons, respectively. Reducing the irrigation levels caused a steady reduction in the root length, which reached its lowest values $(63.83,68.08$ and $76.00 \mathrm{~cm}$ ) in the first, second and 
Table (4): Means of vegetative growth characteristics of Jatropha curcas plants as influenced by irrigation levels (field capacity (F.C.) percentage) in the three seasons of 2012, 2013 and 2014.

\begin{tabular}{|l|c|c|c|c|c|c|c|c|c|c|c|c|}
\hline \multirow{2}{*}{$\begin{array}{c}\text { Treatments } \\
\text { F.C (\%) }\end{array}$} & \multicolumn{3}{|c|}{$\begin{array}{c}\text { Plant height } \\
\text { (cm) }\end{array}$} & \multicolumn{3}{c|}{$\begin{array}{c}\text { Number of leaves } \\
\text { per plant }\end{array}$} & \multicolumn{2}{c|}{$\begin{array}{c}\text { Leaves dry weight } \\
\text { per plant }\end{array}$} & \multicolumn{3}{c|}{$\begin{array}{c}\text { Leaves area } \\
\left(\mathbf{c m}^{2}\right)\end{array}$} \\
\cline { 2 - 13 } & $\mathbf{2 0 1 2}$ & $\mathbf{2 0 1 3}$ & $\mathbf{2 0 1 4}$ & $\mathbf{2 0 1 2}$ & $\mathbf{2 0 1 3}$ & $\mathbf{2 0 1 4}$ & $\mathbf{2 0 1 2}$ & $\mathbf{2 0 1 3}$ & $\mathbf{2 0 1 4}$ & $\mathbf{2 0 1 2}$ & $\mathbf{2 0 1 3}$ & $\mathbf{2 0 1 4}$ \\
\hline $\mathbf{1 0 0} \%$ & 109.25 & 119.00 & 134.83 & 23.33 & 29.83 & 36.00 & 31.09 & 38.43 & 46.44 & 1082.90 & 2050.64 & 3042.80 \\
\hline $\mathbf{9 0} \%$ & 105.00 & 114.50 & 130.16 & 22.16 & 28.33 & 35.00 & 30.00 & 37.60 & 45.43 & 1001.25 & 2018.00 & 3089.66 \\
\hline $\mathbf{8 0} \%$ & 102.00 & 111.33 & 125.41 & 21.83 & 27.66 & 33.33 & 29.65 & 35.92 & 44.12 & 979.76 & 1710.40 & 2606.29 \\
\hline $\mathbf{7 0} \%$ & 99.75 & 108.91 & 122.33 & 20.66 & 26.83 & 33.00 & 29.44 & 35.22 & 42.59 & 912.25 & 1681.94 & 2552.83 \\
\hline $\mathbf{6 0} \%$ & 98.25 & 106.75 & 119.41 & 19.66 & 25.33 & 31.66 & 28.19 & 35.09 & 41.38 & 829.36 & 1366.20 & 2069.33 \\
\hline $\mathbf{5 0 \%}$ & 93.00 & 101.50 & 114.16 & 18.83 & 24.16 & 31.50 & 27.01 & 33.47 & 40.80 & 739.86 & 1104.93 & 1613.20 \\
\hline $\mathbf{4 0 \%}$ & 92.25 & 98.41 & 109.66 & 18.00 & 23.66 & 31.16 & 26.76 & 32.79 & 39.79 & 648.55 & 991.01 & 1482.40 \\
\hline $\mathbf{3 0 \%}$ & 88.50 & 94.50 & 105.75 & 18.00 & 22.50 & 30.00 & 25.23 & 32.24 & 38.39 & 597.70 & 766.64 & 1248.90 \\
\hline $\mathbf{2 0} \%$ & 84.75 & 90.75 & 101.25 & 15.83 & 21.83 & 29.50 & 22.88 & 31.45 & 37.88 & 523.56 & 700.92 & 1069.78 \\
\hline L.S.D. 0.05\% & $\mathbf{6 . 2 3}$ & $\mathbf{4 . 4 9}$ & $\mathbf{3 . 4 6}$ & $\mathbf{1 . 5 4}$ & $\mathbf{0 . 9 9}$ & $\mathbf{0 . 8 4}$ & $\mathbf{2 . 6 2}$ & $\mathbf{2 . 2 5}$ & $\mathbf{1 . 6 4}$ & $\mathbf{5 2 . 0 7}$ & $\mathbf{5 3 . 4 3}$ & $\mathbf{7 8 . 6 7}$ \\
\hline
\end{tabular}

Table (5): Means of stem growth characteristics of Jatropha curcas plants as influenced by irrigation levels (field capacity (F.C.) percentage) in the three seasons of 2012, 2013 and 2014.

\begin{tabular}{|l|c|c|c|c|c|c|c|c|c|}
\hline \multirow{2}{*}{$\begin{array}{c}\text { Treatments } \\
\text { F.C (\%) }\end{array}$} & \multicolumn{2}{|c|}{ Stem diameter $(\mathbf{c m})$} & \multicolumn{2}{c|}{ Stem dry weight $(\mathbf{g})$} & \multicolumn{3}{c|}{ Branch number per plant } \\
\cline { 2 - 11 } & $\mathbf{2 0 1 2}$ & $\mathbf{2 0 1 3}$ & $\mathbf{2 0 1 4}$ & $\mathbf{2 0 1 2}$ & $\mathbf{2 0 1 3}$ & $\mathbf{2 0 1 4}$ & $\mathbf{2 0 1 2}$ & $\mathbf{2 0 1 3}$ & $\mathbf{2 0 1 4}$ \\
\hline $\mathbf{1 0 0} \%$ & 3.08 & 3.62 & 4.37 & 39.98 & 43.47 & 52.52 & 2.33 & 4.66 & 8.00 \\
\hline $\mathbf{9 0} \%$ & 3.05 & 3.60 & 4.27 & 39.10 & 43.34 & 51.36 & 2.16 & 4.50 & 7.33 \\
\hline $\mathbf{8 0} \%$ & 3.04 & 3.58 & 4.26 & 37.42 & 43.08 & 51.18 & 1.83 & 3.66 & 6.50 \\
\hline $\mathbf{7 0} \%$ & 2.91 & 3.51 & 4.01 & 36.64 & 42.20 & 48.20 & 1.66 & 3.33 & 6.33 \\
\hline $\mathbf{6 0} \%$ & 2.83 & 3.49 & 3.88 & 36.61 & 41.88 & 46.60 & 1.50 & 3.33 & 6.16 \\
\hline $\mathbf{5 0} \%$ & 2.70 & 3.48 & 3.88 & 35.07 & 41.88 & 46.58 & 1.50 & 3.16 & 5.83 \\
\hline $\mathbf{4 0} \%$ & 2.67 & 3.38 & 3.84 & 32.50 & 40.66 & 46.07 & 1.33 & 3.00 & 5.00 \\
\hline $\mathbf{3 0 \%}$ & 2.67 & 3.35 & 3.79 & 32.35 & 40.26 & 45.45 & 1.00 & 2.33 & 3.50 \\
\hline $\mathbf{2 0} \%$ & 2.35 & 3.33 & 3.74 & 32.16 & 40.14 & 44.98 & 1.00 & 2.00 & 3.00 \\
\hline L.S.D. 0.05\% & $\mathbf{0 . 1 9}$ & $\mathbf{0 . 1 1}$ & $\mathbf{0 . 1 6}$ & $\mathbf{3 . 1 5}$ & $\mathbf{2 . 3 1}$ & $\mathbf{2 . 2 4}$ & $\mathbf{0 . 3 6}$ & $\mathbf{0 . 7 6}$ & $\mathbf{1 . 3 3}$ \\
\hline
\end{tabular}

third seasons, respectively, in plants irrigated using the $20 \%$ field capacity.

\subsection{Root dry weight (g)}

Data presented in Table (6) show that irrigation of Jatropha curcas plants with irrigation levels significantly decreased the dry weight of roots, compared to plants irrigated with $100 \%$ field capacity (control). In the third season, plants irrigated with $100 \%$ field capacity had the heaviest dry weight of roots (36.00, 42.88 and $48.34 \mathrm{~g}$ per plant) in the first, second and third seasons, respectively. Steady significant reductions in the dry weight of roots was recorded as the lowest irrigation level was

Table (6): Means of root growth characteristics of Jatropha curcas plants as influenced by irrigation levels (field capacity (F.C.) percentage) in the three seasons of 2012, 2013 and 2014.

\begin{tabular}{|l|c|c|c|c|c|c|}
\hline \multirow{2}{*}{$\begin{array}{c}\text { Treatments } \\
\text { F.C. (\%) }\end{array}$} & \multicolumn{3}{c|}{ Root length $(\mathbf{c m})$} & \multicolumn{3}{c|}{ Root dry weight (g) } \\
\cline { 2 - 7 } & $\mathbf{2 0 1 2}$ & $\mathbf{2 0 1 3}$ & $\mathbf{2 0 1 4}$ & $\mathbf{2 0 1 2}$ & $\mathbf{2 0 1 3}$ & $\mathbf{2 0 1 4}$ \\
\hline $\mathbf{1 0 0} \%$ & 81.83 & 89.25 & 101.25 & 36.00 & 42.88 & 48.34 \\
\hline $\mathbf{9 0} \%$ & 78.83 & 85.83 & 97.75 & 34.32 & 40.13 & 46.76 \\
\hline $\mathbf{8 0} \%$ & 76.50 & 83.50 & 94.08 & 33.86 & 39.97 & 46.56 \\
\hline $\mathbf{7 0} \%$ & 74.75 & 81.83 & 91.66 & 32.66 & 38.52 & 45.10 \\
\hline $\mathbf{6 0} \%$ & 73.50 & 80.16 & 89.33 & 31.59 & 38.22 & 44.10 \\
\hline $\mathbf{5 0} \%$ & 69.83 & 76.16 & 85.50 & 29.99 & 37.82 & 43.28 \\
\hline $\mathbf{4 0} \%$ & 69.00 & 73.83 & 82.25 & 29.92 & 37.46 & 42.99 \\
\hline $\mathbf{3 0} \%$ & 66.16 & 70.91 & 79.33 & 29.71 & 37.27 & 41.16 \\
\hline $\mathbf{2 0} \%$ & 63.83 & 68.08 & 76.00 & 25.95 & 36.94 & 40.89 \\
\hline L.S.D. 0.05\% & $\mathbf{4 . 6 5}$ & $\mathbf{3 . 3 6}$ & $\mathbf{2 . 6 6}$ & $\mathbf{2 . 1 5}$ & $\mathbf{1 . 1 1}$ & $\mathbf{1 . 4 4}$ \\
\hline
\end{tabular}


reduced. The $20 \%$ field capacity gave the lowest mean values in the third season $(25.95,36.94$ and $40.89 \mathrm{~g}$ per plant) in the first, second and third seasons, respectively.

\subsection{Fruit yield per plant (g)}

Data presented in Table (7) show that all the tested irrigation level treatments significantly decreased the fruits yield per plant $(\mathrm{g})$ of Jatropha curcas, compared to that of plants irrigated with $100 \%$ field capacity (control). In the third season, plants irrigated with $100 \%$ field capacity had the highest mean fruit yield per plant $(124.88,547.00$ and $1168.76 \mathrm{~g})$ in the first, second and third seasons, respectively. Reducing the irrigation levels caused a steady reduction in the fruit yield per plant, which reached its lowest value $(20.88,91.47$ and $196.08 \mathrm{~g})$ in the first, second and third season, respectively, in plants irrigated using the $20 \%$ field capacity.

\subsection{Seed yield per plant $(\mathrm{g})$}

Data presented in Table (7) show that irrigation of Jatropha curcas plants with irrigation levels significantly decreased the seed yield per plant, compared to plants irrigated with $100 \%$ field capacity (control). In third seasons, plants irrigated with $100 \%$ field capacity had the heaviest seed yield per plant $(92.26,406.10$ and $834.17 \mathrm{~g}$ per plant) in the first, second and third seasons, respectively. Steady significant reductions in the seed yield per plant were recorded as the lowest irrigation level was used. The $20 \%$ field capacity gave the lowest mean values in the third season $(14.00,62.12$ and $127.21 \mathrm{~g}$ per plant) in the first, second and third seasons, respectively.

\subsection{Seed yield per faddan $(\mathrm{Kg})$}

Data presented in Table (7) show that irrigation of Jatropha curcas plants with irrigation levels significantly decreased the seed yield per faddan, compared to plants irrigated with $100 \%$ field capacity (control). In third season, plants irrigated with $100 \%$ field capacity had the heaviest seed yield per feddan (64.58, 284.27 and $583.91 \mathrm{Kg}$ per feddan) in the first, second and third seasons, respectively. Steady significant reductions in the seed yield per faddan were recorded as the lowest irrigation level was reduced, which the $20 \%$ field capacity gave the lowest mean values in third season (9.80, 43.48 and $89.04 \mathrm{Kg}$ per f eddan) in the first, second and third seasons, respectively.

\subsection{Total chlorophyll content (SPAD unit)}

The results presented in Table (8) show that the highest content of total chlorophylls were obtained in plant irrigation with $100 \%$ field capacity $(56.99,57.42$ and 57.32 SPAD) in the first, second and third seasons, respectively. Reducing irrigation levels resulted in gradual significant reductions in the total chlorophyll content, which reached its lowest values (49.13, 50.03 and 50.12 SPAD) in the first, second and third seasons, respectively.

\subsection{Total carbohydrate content $(\%)$}

The data resulting from leaf chemical analysis in Table (8) show that, the total carbohydrates \% in the dried leaves of Jatropha curcas plants was decreased steadily with reduce in the irrigation levels. The highest mean carbohydrate content (21.46, 21.86 and $21.90 \%$ ) in the first, second and third seasons, respectively, was found in the leaves of the control plants, whereas the lowest mean values $(18.70,17.33$ and $17.74 \%)$ in the first, second and third seasons, respectively, were found in plants irrigated with $20 \%$ field capacity.

\subsection{Proline content $(\mathrm{mg} / \mathrm{g})$}

Results of leaf samples taken from plants receiving different irrigation levels Table (8) show that, with reducing the irrigation levels, the proline $\%$ in the dry leaves was generally increased. Accordingly, plants irrigated with $20 \%$ field capacity had the highest mean proline values $(2.40,2.50$ and $2.48 \mathrm{mg} / \mathrm{g})$ in the first, second and third seasons, respectively. On the other hand, plants irrigated with $100 \%$ field capacity had the lowest mean proline values $(1.29,1.15$ and $1.20 \mathrm{mg} / \mathrm{g})$ in the first, second and third seasons, respectively.

\subsection{Relative water content of leaves (\%)}

Results of leaf samples taken from plants receiving different irrigation levels (Table 8) show that, with reducing irrigation level, the relative water content $\%$ in fresh leaves was generally decreased. Accordingly, plants irrigated with $20 \%$ field capacity had the lowest mean relative water content values $(56.25,56.39$ and $53.79 \%$ ) in the first, second and third seasons, respectively. On the other hand, plants irrigated with $100 \%$ field capacity had the highest mean relative water content values (78.96, 78.64 and $76.50 \%)$ in the first, second and third seasons, respectively. The considerable enhancement of relative water content accumulation in plants irrigated may lead to the conclusion that relative water content plays a role in plant drought tolerance. 
Table (7): Means of fruit growth characteristics of Jatropha curcas plants as influenced by irrigation levels (field capacity (F.C.) percentage) in the three seasons of 2012, 2013 and 2014.

\begin{tabular}{|c|c|c|c|c|c|c|c|c|c|}
\hline \multirow{2}{*}{$\begin{array}{l}\text { Treatments } \\
\text { F.C }(\%)\end{array}$} & \multicolumn{3}{|c|}{$\begin{array}{c}\text { Fruits yield per plant } \\
\text { (g) }\end{array}$} & \multicolumn{3}{|c|}{$\begin{array}{c}\text { Seed yield per plant } \\
(\mathrm{g})\end{array}$} & \multicolumn{3}{|c|}{$\begin{array}{c}\text { Seed yield per faddan } \\
(\mathrm{Kg})\end{array}$} \\
\hline & 2012 & 2013 & 2014 & 2012 & 2013 & 2014 & 2012 & 2013 & 2014 \\
\hline $100 \%$ & 124.88 & 547.00 & 1168.76 & 92.26 & 406.10 & 834.17 & 64.58 & 284.27 & 583.91 \\
\hline $90 \%$ & 118.79 & 515.34 & 1103.99 & 83.06 & 363.85 & 748.27 & 58.14 & 254.69 & 523.79 \\
\hline $80 \%$ & 98.70 & 427.49 & & 72.39 & 314.28 & 647.77 & 50.67 & 219.99 & 453.43 \\
\hline $70 \%$ & 80. & 35 & 6 & 60. & 264 & & 42.43 & 185.45 & \\
\hline $60 \%$ & 74.6 & 323.37 & 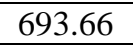 & 51.23 & 223. & 45 & 35.86 & 156.76 & 32 \\
\hline $50 \%$ & 54.16 & 234.10 & 5 & 46.29 & 198.30 & 4 & 32.40 & 138.81 & 288.01 \\
\hline $40 \%$ & 37.95 & 164.54 & 355.60 & 29.72 & 129.61 & 269.45 & 20.80 & 90.72 & 188.61 \\
\hline $30 \%$ & 23.20 & 102.71 & 218.95 & 19.73 & 86.99 & 179.79 & 13.81 & 60.89 & 125.85 \\
\hline $20 \%$ & 20.88 & 91.47 & 196.08 & 14.00 & 62.12 & 127.21 & 9.80 & 43.48 & 89.04 \\
\hline L.S.D. 0.05\% & 15.35 & 53.38 & 121.13 & 9.41 & 31.45 & 62.01 & 6.59 & 24.12 & 43.41 \\
\hline
\end{tabular}

Table (8): Means of chemical constituents of Jatropha curcas plants as influenced by irrigation levels (field capacity (F.C.) percentage) in the three seasons 2012, 2013 and 2014.

\begin{tabular}{|c|c|c|c|c|c|c|c|c|c|c|c|c|}
\hline \multirow{2}{*}{$\begin{array}{l}\text { Treatments } \\
\text { F.C }(\%)\end{array}$} & \multicolumn{3}{|c|}{$\begin{array}{c}\text { Total chlorophyll } \\
\text { content (SPAD unites) }\end{array}$} & \multicolumn{3}{|c|}{$\begin{array}{l}\text { Total carbohydrates } \\
\text { content of leaves }(\%)\end{array}$} & \multicolumn{3}{|c|}{$\begin{array}{l}\text { Proline content of leaves } \\
\text { (mg/g dry weight) }\end{array}$} & \multicolumn{3}{|c|}{$\begin{array}{c}\text { Relative water conten } \\
\text { of leaves }(\%)\end{array}$} \\
\hline & 2012 & 2013 & 2014 & 2012 & 2013 & 2014 & 2012 & 2013 & 2014 & 2012 & 2013 & 2014 \\
\hline $100 \%$ & 56.99 & 57.42 & 57.32 & 21.46 & 21.86 & 21.90 & 1.29 & 115 & 1.20 & 78.96 & 78.64 & 76.50 \\
\hline $90 \%$ & 56.89 & & 55.71 & & & & & & & & & \\
\hline $80 \%$ & 6 & & 55. & & & 2 & & & & & & \\
\hline $70 \%$ & 53.94 & 54. & 54.53 & 20.2 & 20.74 & 20.84 & 3 & & & & & \\
\hline $60 \%$ & .57 & 53.49 & 53.59 & 9.92 & 19.61 & 19.72 & & & & 74.43 & & \\
\hline $50 \%$ & 50.47 & 52.55 & 52.99 & 19.50 & 19.25 & 19.28 & 2.10 & 2.24 & 2.28 & 67.81 & 65.82 & 63.73 \\
\hline $40 \%$ & 50.14 & 52.21 & 52.31 & 19.11 & 18.45 & 18.73 & 2.22 & 2.39 & 2.36 & 64.64 & 62.10 & 61.20 \\
\hline $30 \%$ & 49.72 & 50.62 & 51.04 & 18.81 & 18.04 & 18.33 & 2.35 & 2.40 & 2.3 & 58.26 & 58.12 & 55.97 \\
\hline $20 \%$ & 49.13 & 50.03 & 50.12 & 18.70 & 17.33 & 17.74 & 2.40 & 2.50 & 2.48 & 56.25 & 56.39 & 53.79 \\
\hline L.S.D. 0.05\% & 1.19 & 1.68 & 1.73 & 1.34 & 0.99 & 0.95 & 0.066 & 0.063 & 0.042 & 2.11 & 1.39 & 1.42 \\
\hline
\end{tabular}

\section{DISCUSSION}

The results obtained in Tables (4 to 7) showed that the above-ground vegetative growth including plant height, leaf number per plant, leaf dry weight, leaf area, stem diameter, stem dry weight and branch number per plant were gradually increased as the level of irrigation water was upward. The highest values for all these parameters were obtained due to the use of the high irrigation level (100\% field capacity). Similar results were reported on Jatropha curcas by Mazher et al. (2010) Kesava et al. (2012) and Hussein et al. (2012).

The reductions in these growth parameters due to low irrigation level (20\% field capacity) conditions may be attributed to losses of tissue water which inhibited cell division and enlargement. El -Monayeri et al. (1985) reported that the vital roles of water supply at adequate amounts for different physiological processes such as photosynthesis respiration, transpiration translocation, enzyme reaction and cells turgidity occurs simultaneously. Such reduction could be attributed to a decrease in the activity of meristemic tissues responsible for elongation, as well as the inhibition in photosynthetic efficiency under insufficient conditions (Siddique et al., 1999). Ali et al. (1999) indicated that soil drying decreased leaf growth thereby reducing leaf water status in addition to accumulation of organic solutes to osmotic adjustment which in turn inhibit the incorporation of small substrate molecules into the polymers needed to grow new cell. On the contrary, all water aforementioned vegetative growth parameters root length and dry weight of roots took on similar trend as they were gradually decreased when the irrigation levels were sloping down. These results are on line with those reported by Burman et al. (1991) on Simmondsia chinensis, Uday et al. (2001) and Mazher et al. (2006b) on Taxodium distichum and Achton et al. (2004) on Jatropha curcas. Farahat (1990) on Schinus molle, Schinus 
terbinthifolius and Myoporum ocminatum, Metwally et al. (2002) on roselle and Mazher et al. (2007) on Bauhinia variegata seedlings, found that plant height, stem diameter and fresh and dry weights of leaves, stem and root decreased with prolonging water intervals. The same was true with Shehata (1992) working on Cupressus sempervirens and Eucalyptus camaldulensis, El-Tantawy et al. (1993) on Eucalyptus camaldulensis, Mazher et al. (2006a) on Melia azedarach seedlings and Mazher et al. (2006b) on Taxodium distichum, and Mazher et al. (2010), Kesava et al. (2012) and Hussein et al. (2012) on Jatropha curcas.

Also, Uday et al. (2001) studied the effect of irrigation at (field capacity $10.4 \% \mathrm{w} / \mathrm{w}$ ) 0.2 F.C., 0.5 F.C. and 10 F.C. levels on the growth of Simmondsia chinensis and found that growth was increased with increasing irrigation levels. Sayed (2001) on Khaya senegalensis and Ibrahim (2005) on Simmondsia chinensis, Mazher et al. (2006b) on Taxodium distichum, supplied seedling with three soil moisture content (40, 60 and $80 \%$ of water holding capacity. They observed that plant height, stem diameter, fresh and dry weight of leaves, stem and roots were increased by increasing soil moisture, but root length and fresh and dry weight of roots were decreased. Also, Uday et al. (2001) studied the effect of irrigation at (field capacity $10.4 \%$ w/w) 0.2 F.C., 0.5 F.C. and 10 F.C. levels) on the growth of Simmondsia chinensis and found that growth was increased with increasing irrigation levels. Sayed (2001) on Khaya sensegalensis and Ibrahim (2005) on Simmondsia chinensis, Mazher et al. (2006a) irrigated seedlings of Melia azedarach and Mazher et al. (2007) seedlings of Bouhinia variegata, with different water regimes. They found that chlorophyll (a, b and carotenoid) contents were increased as soil moisture content decreased. In addition to that total sugars, N, P and $\mathrm{K}$ concentration in the leaves were also stimulated gradually by decreasing water supply. While, leaf content of nitrogen, phosphorus and potassium were increased by increasing water supply. Mazher et al. (2006b) on Taxodium distichum found that increasing water supply gradually increased $\mathrm{N}, \mathrm{P}$ and $\mathrm{k}$ uptake in shoot. Data also revealed that proline tended to increase by decreasing water level. Similar results were reported by Mazher et al. (2010) on Jatropha curcas.

As regards the effect of irrigation levels the previous results indicated that $100 \%$ field capacity of different irrigation levels significantly enhanced yield of fruits and seeds of jatropha curcas followed by $20 \%$ field capacity gave the lowest yield. These results are parallel with the findings of El-Shafie et al. (1994) on Roselle plants who cleared that the more frequent irrigation $100 \%$ field capacity was very necessary for producing higher number of fruits, heavier fruits and sepals yield per plant compared with those irrigated $90 \%$ field capacity, while the lowest values in this respect were obtained from $20 \%$ field capacity. Similar results were reported by El-Makawy (1999) on Peganum harmala. Reddy et al. (1996) on castor bean (Ricinus communis) showed that seed yield was markedly decreased when water stress occurred during either the vegetative phase or during the early stages of flowering and on castor varieties, including seed yield Dinesh et al. (2001) on castor plants and Salem (2002) on Simmonds chinensis. The role of water in increasing yield of flowers may be explained by its role in photosynthesis that will be reflected on the relative growth rate and flowering.

From the given data in Table (8) it can be concluded that, increasing irrigation rates caused an increase in the content of total chlorophylls. Accordingly it can be stated that irrigation with $100 \%$ field capacity was the most effective irrigation treatment for promoting the synthesis and accumulation of the pigments. In harmony with these results were those obtained by Ibrahim (2005) on jojoba seedlings, Mazher et al. (2006b) on Taxodium distichum, Kashiwagi et al. (2004) on Cicer arietinum and Mazher et al. (2010) on Jatropha curcas.

From the data given in Table (8) it can be concluded that decreasing irrigation level caused an increase of proline content. This may be due to the proline metabolism which is a typical mechanism of biochemical adaptation subjected to stress condition. The catabolism of proline involves its conversion to glutamic acids. Pyrroline-carboxylate reduction and subsequent metabolism of glutamate by Krebs cycle reaction that release $\mathrm{CO} 2$ as the end product Armestrong (1993) obtained results were in harmony with the findings of Mazher et al. (2006b) on Taxodium distichum, Mazher et al. (2010) and Gabriela et al. (2011) on Jatropha curcas.

\section{Conclusion}

Water stress decreased the growth and development of Jatropha plants but the plants continued to grow even when irrigated with as low as $40 \%$ daily water use. Growth and yield of 
Jatropha would be reduced at suboptimal moisture conditions and its reduction depends on the degree of water stress.

The results indicate that the effect of water stress on plant growth parameters (leaf number, stem diameter, plant height and root length) was significant, but the effect of water stress on chlorophyll levels was not significant. It seems insufficient increase in the activity of antioxidant enzymes in the plant will reduces the plant's ability to tolerate stress and will cause induction of injury to plant lives. Therefore, Jatropha plant with drought avoidance mechanisms, such as: maintaining higher RWC, reduced leaf area and increase in the number of chlorophyll meter, has to confronting to drought stress. Since variations in growth and parameter values were large, further experiments may be needed to reach more solid conclusions.

Chlorophyll is more sensitive to drought and consequently the ratio of total chlorophylls decreases with increasing drought severity. Results found that there was a significant difference in early growth, dry matter accumulation and pigments. The root length, shoot length, total leaf area, fresh and dry weights and total chlorophylls were significantly reduced under water stress treatments.

\section{REFERENCES}

Achton M., Rebens B., Moes W., Mahijis F., Verchet M., Singh V.P. and Mays S. (2004). Root artichicture of the promising biodesel plant jatropha. In A. Moes editox Communication in Agric. and Appl. Biol. Sci., 72(1): 81-85.

Ali M., Jonsen C., Mogensen V., Andersen M. and Henson I. (1999). Root signaling and osmotic adjustment during intermittent soil during sustain grain yield of field grown wheat. Field Crops Res., 62 (1): 35-52.

Armestrong H. (1993). Biochemistry. Oxford Univ. Press, England.

Baquedano F.J. and Castillo F.J. (2006). Comparative ecophysiological effects of drought on seedlings of the Mediterranean water saver Pinus halepensis and waterspenders Quercus coccifera and Quercus ilex. Trees, 20: 689-700.

Barrs D. (1968). Determination of water deficits in plant tissues. Vol.1 pp. 235 - 368. In: water deficits and plant growth. T.T. Kozlowski (ed.). Academic Press, London, UK.
Bates L.S., Waldern R.P. and Teare L. D. (1973). Rapid determination of free proline under water stress studies. Plant and Soil, 39: 205-207.

Burman U., Kathje S., Garg B.A. and Lahiri A.N. (1991). Water management of transplant seedling of Azadirachta indica in aird areas. Forest-Ecol. and Manag., 40: 51-63.

Cornic G. (2000). Drought stress inhibits photosynthesis by decreasing stomatal aperture-not by affecting ATP synthesis. Trends Plant Sci., 5: 187-188.

Dinesh H., Agrawal D.K. and Sundaramoorthy S. (2001). Appraisal of four castor varieties on the basis of different fertility levels and seed yield. Current Agric., 25(112):123-125.

Divakara B.N., Upadhyaya H.D., Wani S.P. and Laxmipathi C.L.(2010). Biology and genetics improvement of Jatropha curcas L.: a review. Appl. Energy, 87: 732-742.

Dong W. (2004). A green energy source for biodiesel extraction. Energy Res. Inform., 20(2):92-94.

Dubios, M., Gilles K., Hamlton J., Rebers P., and Smith F.(1956). Colourimetric method for determination of sugars and related substances. Analytical Chemistry, 28(3): 350- 356

Efeoglu B., Ekmekci Y., Cicek N. (2009). Physiological response of three maize cultivars to drought stress and recovery. S. Afr. J. Bot., 75:34-42.

EI-Makawy M. A. (1999). Effect of certain cultural treatments on growth and chemical compositions of some medicinal plants grown under North Sinai conditions. Ph.D. Thesis, Fac. Agric., ElArish, Suez Canal Univ., Egypt, 139 p.

El-Monayeri M.O., Hagazi M., Ezzat H., Salem H.M. and Tohoun S.M. (1985). Growth and yield of some wheat and barley varieties grown under different moisture stress levels. Annals Agric., Moshtohor Univ., 20: 231-240.

El-Shafie S.A., Mazrou M. M., Eraki M. A. and Saafan S. A. (1994). Effect of watering intervals, nitrogen fertilization levels and their combinations on the growth, yield and the uptake of some nutrient elements. Zagazig J. Agric. Res., 21(1):209-226.

El-Tantawy A., Hanafy M.S. and Shehata, M.S. (1993). Effect of salinity and oil moisture composition of Eucalyptus camaldulensis, 
Dehn. seedings. Minia First. Conf. Hort. Crop, Egypt.

Farahat M.M. (1990). Salinity and tolerance of Scinus molle L., Shinus terbinthifolius and Myoprum acuminatum. Ph.D. Thesis, Fac. of Agric. Cairo, Univ. Egypt.

Gabriela B. Arcoverde, Bruno M. Rodrigues, Marcelo F. Pompelli and Mauro G. Santos (2011). Water relations and some aspects of leaf metabolism of Jatropha curcas young plants under two water deficit levels and recovery. Brazi. Soc. Plant Physiol., 23(2): 123-130.

Hussein M.M., Kamila Y. El-Dieweny and Sawsan Y. El-Faham (2012). Effect of irrigation intervals and nitrogen sources on growth and mineral status of jatropha plants. Middle East J. App. Sci., 2(1): 27 36.

Ibrahim S.M.M. (2005). Responses of vegetative growth and chemical composition of jojoba seedlings to some agricultural treatments. Ph.D. Thesis, Fac. of Agric. Minia Univ. Egypt.

Israelsen O. and Hansen V. (1962). Irrigation, Principles and Practices. John Wiley and Sons, Inc. (pub.) New York, USA.

Jackson N. L. (1958). Soil Chemical Analysis. Constable. 498 p. Ltd. Co., London, U.K.

Kashiwagi J., Krishnamurthy L., Upadhyaya H.D., Krishna H., Chandra S., Vadez V. and Serraj R. (2004). Genetic variability of drought avoidance root traits in the mini-core germplasm collection of chickpea (Cicer arietinum L.). Euphytica, 146: 213-222.

Kesava R., Suhas P. Wani, Piara Singh, Srinivas K., Ch. Srinivasa Rao (2012). Water requirement and use by Jatropha curcas in a semi-arid tropical location. Biomass and Bioenergy, 39 : 175- 181.

Kozlowski T.T. and Pallardy S.G. (2002). Acclimation and adaptive responses of woody plants to environmental stresses. The Bot. Rev. 68(2): 270-334.

Kumar D., Singh S., Sharma R., Kumar V., Chandra H. and Malhotra K. ( 2011). Above-ground morphological predictors of rooting success in rooted cuttings of Jatropha curcas L. Biomass and Bioenergy, 35 (9): 3891-3895.

Maes W.H., Achten W.M., Reubens B., Raes D., Samson R. and Muys B. (2009). Plantwater relationships and growth strategies of Jatropha curcas L. seedlings under different levels of drought stress. J. Arid Environ., 73: 877-884.

Mazher A. A. M. and Zaghloul S. M. (2006a). Increasing water deficiency tolerance of Melia azedarach seedlings through application of iron World J. Agric. Sci., 2: 346-351.

Mazher A.A.M., Zaghloul S. M. and Yassen A.A. (2006b). Impact of Boron fertilizer on growth and chemical constituents of Taxodium distichum grown under water regime. World J. of Agric. Sci., 2 (4): 412-420.

Mazher A.A.M., Yassen A.A. and Zaghloul S. M. (2007). Influence of foliar application of potassium on growth and chemical composition of Bauhinia variegata seedlings under different irrigation intervals. World. J. Agric. Sci., 3(1): 2331.

Mazhar A.A. M., Abd El-Aziz N. G. and El.Habba E. (2010). Impact of different soil media on growth and chemical constituents of Jatropha curcas L.seedlings grown under water regime. J. of Amer. Sci., 6(8): 549- 556.

Metwally M. Mazrou, Afify M.M., Hend E. Wahba, Makarem A. Mohamed, Eraki M.A. and Mahfous S. (2002). Effect of irrigation and vapor Gard on growth, yield and chemical composition of roselle. Plant Bull. National Research Center, Egypt, 27: 533-548.

Ogunwole J.O., Chaudhary D.R., Ghosh A., Daudu C.K., Chikara J. and Patolia J.S. (2008). Contribution of Jatropha curcas to soil quality improvement in a degraded Indian entisol. Acta Agric. Sc and B: Plant Soil Sci., 58: 245-251.

Openshaw K. (2000). A review of Jatropha curcas: an oil plant of unfulfilled promise. Biomass Bioenergy, 19: 1-15.

Osipova S.V., Permyakov A.V., Permyakova M.D., Pshenichnikova T.A. and Borner A. (2011). Leaf dehydroascorbate reductase and catalase activity is associated with soil drought tolerance in bread wheat. Acta Physiol. Plant, 33:2169-2177.

Reddy G. S., Rao D. G., Venkateswarlu S. and Maruthi V. (1996). Drought management options for rain fed castor in alfisols. J. Oil Seeds Res., 13 (2): 200-207.

Ritchie J. T. (1974). Atmospheric and soil water influences on the plant water balance. Agric. Meteorol., 14: 183-198. 
Salem S. M. M. (2002). Effect of some agricultural treatments on jojoba plants grown in sandy soils. M.Sc. Thesis, Fac. Agric., Zagazig Univ., Egypt, 223 p.

Sayed M. (2001). Effect of some agriculture treatments on growth and chemical composition of some woody trees seedlings. Ph.D. Thesis, Fac. of Agric. Minia Univ. Egypt.

Shehata M.S. (1992). Effect of salinity and soil moisture content seedling of Cuperssus sempervirens and Eucalyptus camaldulensis. Ph.D. Thesis, Fac. of Agric. Cairo Univ. Egypt.

Siddique M., Hamid R.B. and Islam M.A. (1999). Drought stress effect on photosynthetic rate and leaf gas exchange of wheat. Botanical Bull. of Academia Sinica, 40: 141-145.

Silva E.N., Ribeiro R.B., Ferreira-Silva S.L., Viegas R.A. and Silveira J.A.G. (2010). Comparative effects of salinity and water stress on photosynthesis, water relations and growth of Jatropha curcas plants. J. Arid Environ. ,74: 1130-1137.

Snedecor G. and Cochran W. (1980). One-way Classification Analysis of Variance. In: Statistical Methods. (8 Edition). Chapter 12, pp. 217-236 Iowa State University Press. Ames. Iowa, USA.
Souza R.P., Machado E.C., Silva J.A.B., Lagoa A.M. and Silveira J.A.G. (2004). Photosynthetic gas exchange, chlorophyll fluorescence and some associated metabolic changes in cowpea (Vigna unguiculata) during water stress and recovery. Evriron. Exp. Bot., 51: 45-56.

Takeda Y. (1982). Development study on Jatropha curcas (sabudum) oil as a substitute for diesel engine oil in Thailand. J. Agric. Assoc., 120: 1-8.

Uday B., Bohra M.D., Harsh L.N., Tiwari J.C. and Burman U. (2001). Water relation and growth of Simmondsia chinensis and Prosopis Juliflord seedlings at nursery stage. Indian Forester, 127: 351-357.

Wu F.Z., Bao W.K., Li F.L. and Wu N. (2008). Effects of drought stress and $\mathrm{N}$ supply on the growth, biomass partitioning and water use efficiency of Sophora davidii seedlings. Environ. Exp. Bot., 63:248255.

Yadava U. (1986). A rapid and non destructive method to determine chlorophyll in intact leaves. Hort. Sci., 21(6): 1449-1450.

Zhang M., Chen Q. and Shen S. (2011). Physiological responses of two Jerusalem artichoke cultivars to drought stress induced by polyethylene glycol. Acta Physiol. Plant. 33: 313-318.

\section{تأثير مستويات مختلفة من الرى على النمو والإزهار والمكونات الكيميائية

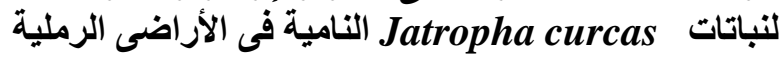

$$
\text { قسم بحوث الحدائق النباتية بانطونيادس - معهد بحوث البساتين - مركز البحوث الزر اعية ـ الإسكندرية ـ مصر الثنهورى }
$$

\section{ملخص}

أجريت هذه الدر اسة خلال المو اسم 2012, 2013, 2014 على نبات الجاتروفا النامى فى أصص بلاستيكية ذات قطر

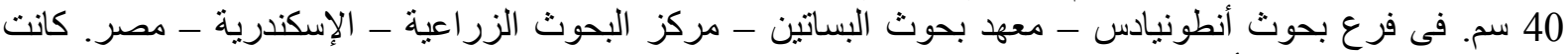

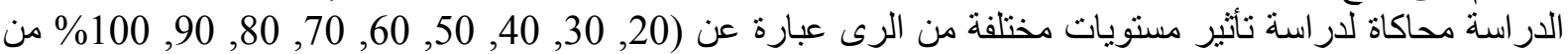
السعة الحقلية للتربة) على النمو الخضرى و إنتاج المحصول وبعض التئة التحليلات الكيمائية لنبات الجاتروفا النامى فى تربة

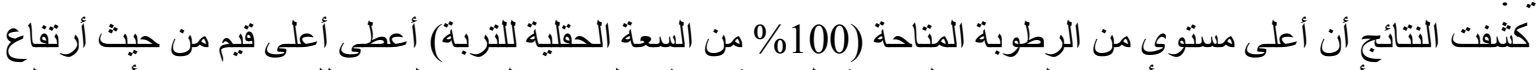
رملية.

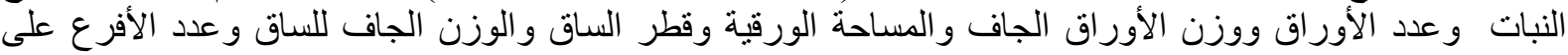
النبات وطول الجذور ووزن الجذور الجاف ومحصون الثون الثمار للنبات و محصول البذور للنبات ومحتوى الكلوروفيل الكلى ومحتوى الكربو هبدرات ومحتوى البرولين , المحتوى المائى النسبى للأوراق.

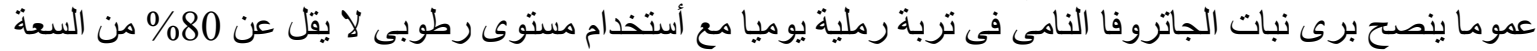

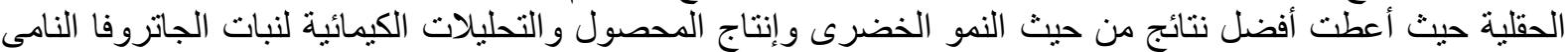

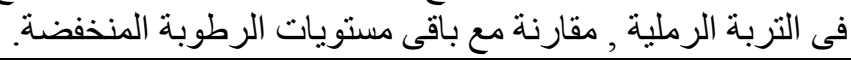
المجلة العلمية لكلية الزراعة -جامعة القاهرة ـ المجلد (66) العدد الثانى (ابريل 2015) : 130-141. 